\title{
Socio-Economic Evaluation of Improved Forage Technologies in Smallholder Dairy Cattle Farming Systems in Uganda
}

\author{
Alice Turinawe \\ Department of Agribusiness and Natural Resource Economics, Makerere University \\ P.O. Box 7062, Kampala, Uganda \\ Tel: 256-782-324-841Ｅ-mail: aturinawe@agric.mak.ac.ug \\ Johnny Mugisha (Corresponding author) \\ Department of Agribusiness and Natural Resource Economics, Makerere University \\ P.O. Box 7062, Kampala, Uganda
}

Tel: 256-773-155-702Ｅ-mail: jomugisha@agric.mak.ac.ug

Jolly Kabirizi

National Livestock Resources Research Institute (NaLIRRI)

P. O. Box 96, Tororo, Uganda

Tel: 256-772-434-937Ｅ-mail: jkabirizi@hotmail.com

Received: August 9, 2011

doi:10.5539/jas.v4n3p163
Accepted: August 23, $2011 \quad$ Online Published: December 29, 2011

URL: http://dx.doi.org/10.5539/jas.v4n3p163

This Research was supported by The Belgian Technical Cooperation (BTC), and National Livestock Resources Research Institute (NaLIRRI)

\begin{abstract}
Smallholder dairy cattle producers in Uganda face major production constraints including inadequate and poor quality feeds. Forage technologies have been widely recommended to alleviate this problem. This study aimed at comparing profitability of dairy cattle enterprises using improved forage technologies (IFTs) with those using local technologies, and determining factors affecting the use of IFTs among smallholder dairy farmers. Data were collected from 121 farmers in Soroti district. Descriptive statistics, partial budget analysis, probit model, and Ordinary Least Squares were used to analyze data. Results indicated that farmers using IFT had significantly $(\mathrm{p}<0.01)$ higher gross margins than those using local feeding methods. Probit model results indicated that profitability of technology influenced the decision to use IFT when interacted with improved cattle breed. The decision to use IFTs had a positive significant $(\mathrm{p}<0.1)$ relationship with profitability of dairy cattle enterprises. Policies targeting efficient dissemination of IFTs are recommended to improve profitability.
\end{abstract}

Keywords: Dairy farmers, Forage technologies, Probit, Profitability

\section{Introduction}

Livestock production is one of the major economic activities for $80 \%$ of Ugandans, especially the rural population that depend primarily on agriculture for their livelihood (Ministry of Finance, Planning and Economics Development, MFPED, 2001). However, Uganda's smallholder dairy cattle farming is still dependent on natural pastures, which are deficient in terms of nutrition. The nutritive value of the natural forages varies seasonally, with significant decreases in quality and quantity during the dry season. IFAD (2007) showed that inadequate livestock nutrition and poor feeding practices are the primary reasons for low animal production, and a major factor affecting the development of viable livestock industries in developing countries. 
Adequate quantities of high-quality feed are necessary for profitable livestock production. There are forage technologies such as grass-legume mixtures, cereal-legume intercrops, fodder trees, silage and hay making (Kabirizi, 2006), whose use can help in mitigating feed shortages. Some of these technologies along with improved cows are being disseminated in Soroti district in Uganda. In this area, some farmers have taken up these technologies with the help of the National Livestock Resources Research Institute (NaLIRRI) under National Agricultural Research Organization (NARO), and NGOs such as Send a Cow, World Vision and Soroti Catholic Diocese Integrated Development Organization (SOCADIDO). Wünscher et al. (2004), however, noted that the prerequisite for adoption is when the new improved forage presents a solution to existing problems. Despite all other non-monetary or non-profit factors that could deter technology use, farmers tend only to use technologies that they consider profitable (Kabirizi, 2006). While studying the adoption of land management technologies in Uganda, Sserunkuuma (2005) found that it is possible for improved technologies not to be adopted if they are of low profitability; if the returns do not justify the effort required.

Related studies have been carried out to identify factors that influence the adoption of new agricultural technologies (Fufa and Hassan, 2006; Salasya et al., 2007). In almost all these, household level characteristics such as age and education of the household head, household size, landholding size, access to credit and extension services have been considered as explanatory variables. Teklewold et al. (2006) found that the adoption of poultry technology was positively affected by sex of the household head, family size, and availability of supplementary feed, credit and extension service and extent of expected benefit from poultry. Similarly, Salasya et al. (2007) found that education of a farmer, distance to the market and number of cattle owned significantly influenced the adoption of maize hybrid in western Kenya. In Eastern Uganda, Mugisha et al. (2004) found that the farmer's education, family size, association membership, extension visits, access to credit, size of cultivatable land, and household income influenced adoption of Integrated Pest Management technologies. According to Place et al. (2000), the demand for labor has direct implications for the adoption of agricultural technologies, with larger families more likely to adopt.

Some empirical studies on factors affecting livestock profitability indicated that larger herd sizes and higher milk production per cow are associated with greater profitability (Winsten et al., 2000; Gloy et al., 2002). Stocking density was also found to increase technology profitability in dairy farms (Kauffman and Tauer, 1986). Foltz and Lang (2003), in a study conducted in Northeastern Connecticut dairy farms, found that greater grazing technology use, despite the increased productivity it results into, produces significantly lower profits. On the contrary, Gloy et al. (2002) found that the use of modern grazing technology increased dairy profitability among the New York farms. Household and farm level factors have also been found to influence profitability of dairy enterprises. Hanson et al. (1998) found that farmers using more intensive grazing practices tended to be younger and the farms had greater profitability levels. Conversely, Foltz and Lang (2003) found that age of a farmer significantly reduced dairy profitability levels, while education had a significant impact on profitability. White et al. (2002) found that, although grazing cows on average produced $11.1 \%$ less milk than cows fed in confinement facilities, the feed costs associated with producing the milk were lower in the grazing system. This resulted in similar profitability levels in the two feeding systems. Hanson et al. (1998) also observed no difference in profitability between farms that adopted grazing system and those that used zero grazing in Pennsylvania dairy farms.

Although there is a growing body of research work on the profitability of improved forage technologies in Uganda, the existing studies so far appear to concentrate on comparative analysis of different improved forage technologies while ignoring local technologies. Thus, this study sought to address the following research questions: Does it pay to switch from local livestock feeding methods to the improved forage technologies? What are the key driving determinants that influence the farmer's decision to use improved forage technology? Is it the profitability of the forage technology or the type of the cattle breed or the combination of both factors?

\section{Methodology}

\subsection{Study area}

The study was conducted in Soroti district in Eastern Uganda. This district was selected because it is one of the areas in Uganda that annually suffers long dry spells that leave nearly all pastures dry leading to scarcity of livestock feeds. Major economic activities for farmers in the area are crop and livestock production. Dairy cattle farming systems include the intensive (zero grazing), semi-intensive and extensive grazing production systems.

\subsection{Description of the forage technologies and sampling procedure}

The forage technologies that were evaluated in this study are the traditional forage technology (local grazing grass) and improved forage technologies. The improved forage technologies were those introduced by National Livestock Resources Research Institute (NaLIRRI) project. These were: 1. Maize-cowpeas intercrop, 2. 
Maize-lablab intercrop, 3. Sorghum-lablab intercrop, 4. Sorghum-cowpeas intercrop, 5. Chloris gayana-Desmodium-Siratro intercrop, 6. Elephant grass-Desmodium intortum mixture and 7. Elephant grass occasionally supplemented with grazing. These technologies had been distributed to farmers in Soroti district by the NaLIRRI project, with the aim of determining which of them could lead to higher milk yield and hence more profits. However, the sample of farmers under NaLIRRI project was too small to allow meaningful econometric analysis and draw concrete conclusions. The study therefore had to increase the sample size by selecting NonNaLIRRI project farmers who had received similar technologies from other NGOs.

For the NaLIRRI project farmers, purposive sampling procedures were used. Two sub-counties (Gweri and Arapai) were purposively chosen where intensive dairy cattle production was a priority enterprise. From each of the selected sub-counties, one village was also purposively selected. A list of improved dairy cattle farmers having improved cattle was compiled (this was one of the basic requirements of the NaLIRRI project). The compiled list indicated that only 40 farmers had been given improved forage technologies by the NaLIRRI project, and 31 of them had planted the materials they were given. All the 31 farmers were selected.

In addition to the selected NaLIRRI project farmers, 12 more farmers supported by some NGOs such as Send a Cow, World Vision, and Soroti Catholic Diocese Integrated Development Organization (SOCADIDO) with similar improved forage technologies but within the selected areas were randomly chosen. These were also obtained from a list of those using improved forage technologies that were being promoted by the NGOs. A total of 43 farmers using improved forage technologies ( 31 farmers from NaLIRRI project and 12 from other NGOs) Note $1^{-}$ thus participated in this study. In addition, in the same areas where the NaLIRRI project was operating, 78 farmers who were not using any of the improved forage technologies but had milking cows (local or improved) were randomly selected. These were considered as farmers using traditional technology for comparison purposes.

Data were collected in May 2008 from the selected farmers using a structured questionnaire. The questionnaire was pre-tested on both the farmers using improved forage and those using traditional technologies. The data collected included: type of forage technology disseminated and its uptake, quantity and cost of inputs allocated to different forage and milk production, marketing and transaction costs and milk consumption. The data were entered into Statistical Package for Social Scientists (SPSS) and analyzed using STATA 10.

\subsection{Analytical methods}

The analytical methods that were used included partial budget analysis, the probit model, and the regression model. Testing of the hypothesis that improved forage technologies are more profitable than the local technology was done through a partial budget (Swinkels et al., 2005) analysis that calculated gross margin over improved forage expense. In this analysis, additional income was taken as the additional revenue from milk sold and consumed. Reduced expenses were taken as the reduced labor costs in terms of time spent grazing and reduced costs of buying feeds/forages, or looking for wild feeds for cattle. Additional expenses included labor (family and hired), cost of veterinary services, and cost of feed.

The probit model was run to determine factors affecting the use of improved forage technologies and to test the hypothesis that profitability of a forage technology has an influence on whether a farmer uses the technology or not. The model was also used to test the hypothesis that there exists an interaction effect between profitability and the type of cattle breed (particularly improved cattle) on use of improved forage technology. The endogeneity problem brought about by the fact that use of the forage technology is jointly determined with the profitability of that technology was first tested for; and it was this test that led to the use of the probit model (Wooldridge, 2002). The model assumes an underlying normal distribution and has the advantage of giving efficient, unbiased, and normally distributed estimates (Lapar and Pandey, 1999). Specification of the probit has advantages over logit models in small samples (Fufa and Hassan, 2006), and since this study had particularly small samples, this model was thought suitable. Several studies on agricultural technology adoption have used the probit model including Foltz and Lang (2003), Servier and Lee (2004), and Fufa and Hassan (2006). Variables used in the model were farmer's age, formal education, number of farmer's dependants, size of land owned (hectares), number of extension visits a farmer received, labor cost in livestock production per season (Ushs), distance to the nearest market (km), membership to any farmers' group, access to any form of credit, experience in livestock production, number of local and improved cows owned, and gross margin for the livestock enterprise.

The probit model was stated as:

$$
w_{i}^{*}=\alpha \pi_{i}+\theta B_{i} \pi_{i}+\beta X_{i}+u_{1}
$$




$$
\begin{aligned}
& \pi_{i}=\gamma X_{i}+u_{2} \\
& w_{i}=\left\{\begin{array}{lc}
1, & w_{i}^{*}>0 \\
0, & \text { otherwise, }
\end{array}\right.
\end{aligned}
$$

Where

$w_{i}^{*}$ is a latent variable for farmer $i$; $\theta$ is the parameter to determine whether there is an interaction effect between the type of cattle breed $\left(B_{i}\right)$ and profitability $\left(\pi_{i}\right) . X_{i}$ is a vector of exogenous regressors, while $\alpha, \beta$ and $\gamma$ are respective unknown parameters, and $u_{1}$ and $u_{2}$ are error terms.

Equation ( $1 \mathrm{~b}$ ) is a reduced form for $\pi_{i}$, which is an endogenous profitability variable if $u_{1}$ and $u_{2}$ are correlated. If $u_{1}$ and $u_{2}$ are independent, there is an endogeneity problem. Equation (1c) assumes that there is a threshold level of the latent variable, such that if $w_{i}^{*}$ exceeds zero, the farmer's decision would be to use the improved forage technology $\left(w_{i}=1\right)$, otherwise the farmer $\operatorname{would} \operatorname{not}\left(w_{i}=0\right)$.

To correct for self selection bias, instrumental estimation (Wooldridge, 2002) was used. The instrumental variable probit model estimated was specified as;

$$
w_{i}=\beta_{0}+\beta_{1} X_{1}+\ldots+\beta_{T} X_{T}+\theta B_{i}\left(\pi_{i}=\gamma_{1} X_{1}+\ldots+\gamma_{T} X_{T}+\alpha Z_{i}\right)+\varepsilon_{i}
$$

Where

$X_{1} \ldots X_{T}$ are some of the explanatory variables responsible for explaining the variation in use of forage technologies. $Z_{i}$ is a vector of explanatory variables that directly affect dairy profitability but do not directly affect the use of improved forage technologies such as the means of transporting milk to the market place and access to veterinary services. $\varepsilon_{i}$ is the error term. Other terms are as defined earlier.

The linear regression equation estimated was;

$$
\pi_{i}=\gamma X_{i}+\delta w_{i}+e_{i}
$$

Where

$\pi_{i}$ is the profit variable for farmer $i, X_{i}$ is a vector of explanatory variables, $w_{i}$ is a dummy variable for use of improved forage technology ( $w_{i}=1$, if technology is used, 0 otherwise), $e_{i}$ is a random disturbance assumed to be normally distributed.

Similar to equation 1, there is still a problem of self selection bias because farmers themselves decide whether to use forage technology or not. As may be expected, the typical farmer who chooses to use forage technology will likely have relatively high milk output and hence higher profitability levels even if forage technology is not used. This implies that the dummy variable $w_{i}$ cannot be treated as an exogenous variable. Otherwise, estimating equation (3) by ordinary least squares (OLS) yields inconsistent estimates of the parameters. Thus, from equations (1) and (3), the expected profit, $\pi_{i}$ can be obtained by following Wooldridge (2002) and Greene (2003).

$$
\begin{gathered}
E\left[\pi_{i}\right]=E\left[\pi_{i} \mid w_{i}=1\right] * \operatorname{prob}\left(w_{i}=1\right)+E\left[\pi_{i} \mid w_{i}=0\right] * \operatorname{prob}\left(w_{i}=0\right) \\
=\gamma X_{i}+\delta \Phi\left(\beta X_{i}\right)
\end{gathered}
$$

Where $\Phi$ is cumulative standard normal function. Thus, $\Phi\left(X_{i} \beta\right)$ serves as the instrumental variable for $\pi_{i}$ in equation (3) to avoid the biased estimators. Using this framework, the parameters of both the profitability model and the use of improved forage technology model are obtained. In order for $\Phi\left(X_{i} \beta\right)$ to serve as a valid instrument, the exclusion restriction is needed to identify the parameters (Wooldridge, 2002); the factors that influence the decision to use the improved forage technology, but do not affect dairy profitability directly. Training or extension on improved forage technologies, method of disseminating the technologies, and forage seed availability were factors used to satisfy exclusion restriction.

The empirical model was estimated in a two-stage procedure: First, by estimating the binary response equation (1) by maximum likelihood to obtain fitted probabilities $\Phi\left(X_{i} \beta\right)$. Second, by estimating

$$
\pi_{i}=\gamma_{0}+\gamma X_{i}+\delta w_{i}+e_{i}
$$

by IV using instruments $\Phi\left(X_{i} \beta\right)$ and $X$, where $\gamma_{0}=$ constant. The final empirical estimation was; 


$$
G M=\gamma_{0}+\gamma_{1} X_{1}+\gamma_{2} X_{2}+\gamma_{3} X_{3}+\gamma_{4} X_{4}+\gamma_{5} X_{5}+\ldots+\gamma_{12} X_{12}+\Phi\left(\beta X_{i}\right)+e_{i}
$$

Where $\mathrm{GM}=$ gross margin.

The variables used in the linear regression model, and their expected signs (in parentheses) included; use of the improved forage technology $(+)$, total land size owned $(+)$, distance to markets $(+)$, number of monthly visits by extension agents $(+)$, experience in livestock production $(+)$, milking herd size $(+)$, age of the farmer $(+/-)$, age of the farmer squared (+/-), education level of the farmer $(+)$, access to credit, stocking density (number of cows per unit grazing area) $(+)$, number of farmer's dependants $(-)$, and membership to any farmers' group $(+)$.

\subsubsection{Empirical estimation procedure and hypothesis testing}

The estimation of the models outlined above followed a series of regression diagnostics. The variables used in the regressions were first checked for normality and symmetry using Exploratory Data Analysis (EDA). This was done by checking the coefficient of kurtosis and skewness. Regression diagnostics included tests for multicollinearity, heteroscedasticity and self-selection bias. Multicollinearity was tested using variance inflation factor (VIF) and the correlation matrix, while heteroscedasticity was checked using Breusch-Pagan/Cook-Weisberg tests (Wooldridge, 2002; Greene, 2003). The leverage-versus-squared-residual plot was used to identify regression outliers and leverage points. Self-selection bias was checked by testing for exogeneity of gross margin in the improved forage technology model following a procedure in Wooldridge (2002). To test whether there existed an interactive effect between profitability and the type of cattle breed in the improved forage technology model, the tests done included the Likelihood ratio test (Wooldridge, 2002), the Lagrange Multiplier test, and the Wald test (Braumoeller, 2004; Brambor et al., 2006).

\section{Results and Discussions}

This study refers to the farmers who were given improved forage technologies by NaLIRRI project and those who were using forage technologies from other NGOs as users of improved forage technology (IFT). Farmers who were not given improved forage technologies and were using local feeding methods are referred to as non-users. The use of local grazing grass is referred to as local forage technology. The observations on the seven improved forage technologies mentioned in the methodology were pooled and collapsed to constitute a general reference as "use of improved forage technologies". This was done due to limited number of observations per technology.

\subsection{Resource endowment of the cattle farmers}

On average, cattle farmers that participated in the study owned 16.2 hectares of land (Table 1). These were mainly acquired through inheritance. The farmers allocate a small proportion $(23 \%)$ of their total land to cattle keeping. Both users and non-users of improved forage technologies (IFT) owned about the same number of local cows, but the users had significantly $(\mathrm{P}<0.01)$ more improved cows than their counterparts.

\subsection{Production costs and milk production by users and non-users of IFT}

Results in Table 2 indicate that the farmers using the improved forages had significantly lower $(\mathrm{p}<0.05)$ production costs than the non-users. The costs incurred by the non-users were about 1.5 times more. This difference was largely due to labor costs. Non-users incurred significantly $(\mathrm{P}<0.05)$ higher labor costs than their counterparts. The possible explanation for this is that for non-users, more hours are spent grazing the cattle than for the users who can graze less and supplement their cattle with the cut feeds, thus saving some working hours for other activities.

Regarding milk production, Table 3 shows that farmers using improved forage technologies produced more milk per day than non-users by a significant margin $(\mathrm{p}<0.01)$ of 3.5 liters and their milk yields (liters per cow per season) were also significantly higher $(\mathrm{P}<0.01)$.

From results in tables 2 and 3, farmers using IFT had productivity advantages over the non-users. Production costs per liter per season (six months) of IFT users were as low as Ushs. 70, more than three times less than the costs incurred by the IFT non-users (Ushs. 248 per liter per season). This finding conforms to earlier work of Gloy et al. (2002) who found that the rate of returns on inputs for grazing dairy farms in New York was largely lower than that of non-grazing farms. This implies that amount of milk produced per cow largely depends on the quality of feeds. The natural grasses/forages in Soroti are usually over grown, and inadequate in quantity which may explain the low nutritive value and high cost of grazing, and hence low milk production. 


\subsection{Profitability of the cattle enterprises}

A partial budget for the farmers who were using improved forage technologies and those who were using the local technology is presented in table 4 . Results show that using IFT was considerably more profitable $(\mathrm{P}<0.01)$ than using local forage technology. Farmers using IFT generated a five times bigger margin per cow per season than the non-users. This is consistent with the hypothesis that IFTs are more profitable than the local feeding methods of smallholder dairy cattle production.

The results further revealed that farmers using local grazing methods had an average return on inputs of $3.1 \%$, a profitability level that is competitive with "safe" input investments, but not as competitive as $12.3 \%$ for farmers using IFT. The lower return on inputs for the former was attributed to high labor cost requirements or to unobservable management factors. The significantly $(\mathrm{p}<0.01)$ higher return on inputs attained by farmers using IFT was related to advantages of commercialized production, higher per cow milk production levels and greater labor efficiency.

\subsection{Factors affecting adoption of improved forage technologies}

Estimation of the binary probit model explained the behavior of forage technology usage by cattle farmers. Results of the Likelihood Ratio test and the Wald test showed that, the inclusion of interaction terms of gross margin and number of improved cows, and gross margin and number of improved cows squared increased the model fit significantly $(\mathrm{P}<0.05)$. This was consistent with the hypothesis that there exists an interaction effect between the improved cattle breed and the profitability of the forage technology on use of IFT. Put differently, rearing improved cattle breeds together with increased profitability of forage technology significantly influence the decision to use improved forage technology.

Results showed that the hypothesis that profitability of forage technology alone influences the decision to use improved forage technology does not hold for farmers in Soroti district. This is inconsistent with earlier work of Sserunkuuma (2005) who found that profitability of the technology significantly enhances the use of land technologies. The results instead indicated that profitability contributes significantly to decision making involving the use of IFT when interacted with the improved cattle breed.

In particular, the results on the interaction of gross margin and improved cows indicated an inverse relationship with the use of IFT. This means that an increase in the number of improved cows together with increased profitability enhances the use of IFT significantly $(p<0.01)$. But as the number of improved cows along with greater profitability increase beyond a certain point, the likelihood to use IFT reduces substantially $(p<0.01)$. This implies that number of improved cows and the profitability level are complementary factors cattle farmers consider when making the decision to use IFT. To further explain the negative effect in the inverse relationship, a large increase in the number of improved cows with increasing profits serves as an incentive for farmers to expand the scale of operation. Increase profits imply that, farmers are more likely to have more resources especially in terms of land, some of which can be allocated to grazing. This in turn may lead to a reduction in the use of IFT.

Without the interaction effect of gross margin, however, the number of improved cows owned had a significant "U-shaped" relationship with the use of IFT. This means that farmers with fewer or no improved cows are less likely to use IFT, but the likelihood to use IFT increases as they acquire more improved cows. Specifically, from the regression results, farmers begin to use IFT when they acquire one improved cow (From Table 5, using the coefficients on the number of improved cows and its squared term, $x=-(-3.368 / 2 * 2.064)=0.816 \cong 1.00)^{\text {Note } 2}$.

Similarly, livestock farmers with local cows less than ten are less likely to use IFT, but they do so after acquiring ten local cows. This is possible in the study area where farmers with fewer local cows could afford to graze them on the limited communal grazing land and other swampy areas. But as the herd size increases, the need to supplement grazing with improved forages arises because of lack of sufficient grazing grounds.

There was also a significant "U-shaped" relationship between age of a farmer and the use of IFT. The likelihood to use IFT reduces significantly ( $\mathrm{p}<0.01$ ) by $15.5 \%$ until the farmer is 48 years old, when his/her chances of using IFT increase by $0.1 \%$. Earlier work by Adesina and Zinnah (1993), and Fufa and Hassan (2006), found that age of a farmer reduces the probability of using agricultural technologies, whereas Obonyo (2000) reported a positive relationship. This implies that there is a non-linear relationship between age and the use of agricultural technologies (Rogers, 1983). In Soroti district, the younger farmers are less likely to keep cattle. This partly explains why they do not use improved forage technologies.

Results in table 5 also indicated that the less educated farmers were more likely to use the forage technologies. The marginal effects on the education variable indicated a significant reduction $(\mathrm{p}<0.05)$ of $9 \%$ on the probability to 
use IFT. This is contrary to expectation and to findings by some studies (Obonyo, 2000; McBride et al., 2004; Mugisha et al., 2004; Salasya et al., 2007) which reported that education enhances the use of agricultural technologies because more educated farmers have a better opportunity to acquire and process information as well as understand the technical aspects of new technologies. However, the negative impact of education on use of IFT is possible where more highly educated farmers are engaged in other gainful employment whose returns are higher (Sserunkuuma, 2005).

It was also observed that membership to farmer groups had a significant $(\mathrm{p}<0.01)$ and positive influence on use of IFT. This finding is similar to that of Mugisha et al. (2004), who found that membership in an association significantly influenced adoption of IPM groundnut technologies in Eastern Uganda. Farmers in groups are more exposed to inputs and technical knowledge as compared to their counterparts.

Results further indicated that access to credit by the IFT users had a positive but a weak impact $(p<0.1)$ on use of forage technology. Access to credit increased the probability of using IFT by $38 \%$. This agrees with the findings of Mugisha et al. (2004), that access to credit was positively related with adoption. This can be attributed to the fact that some of the investments (additional labor and other inputs) need more money, which some potential users of improved technologies may not have.

The significant and negative relationship between farm size and use of IFT, similar to the findings of Adesina and Zinnah (1993), suggests that any additional land increase is either diverted to paddocking due to scale diseconomies of using IFT or allocated to other uses such as crop production. For every additional hectare acquired, the probability to use IFT reduces by $34.3 \%$.

The number of extension visits did not have a significant effect on use of improved forage technologies. This is possible where the technology and knowledge being disseminated by extension workers is irrelevant to livestock production.

\subsection{Factors responsible for profitability of cattle enterprise}

Some of the farmers were found to own both local and improved breeds. Results in Table 6 show estimates of profitability model for the entire sample, i.e., pooled observations for farmers using IFT and those not using. The estimated model explained $55 \%$ of the variation in the dairy profitability model and has a highly significant F-statistic $(\mathrm{p}<0.01)$.

The estimated coefficients for use of improved forage technologies suggest increased milk profitability level per cow per season, ceteris paribus, which is consistent with the study hypothesis. Use of improved forage technologies amounts to better feeding of the livestock, thus increasing milk output.

Stocking density was found to be significant $(\mathrm{p}<0.05)$ and positively related to profitability level. A higher stocking density leads to an increase in profitability levels. Kauffman and Tauer (1986) also found that increasing stocking density increased profitability in dairy farms. Ealier studies (Winsten, et al., 2000; Gloy et al., 2002) noted that increasing the number of cows on a farm increases dairy profitability. However, results also indicated that stocking density can only positively impact on profitability up to a certain point. This is due to diminishing returns resulting from increasing herd size on fixed grazing land, especially if the optimal stocking levels are exceeded.

There was also a positive relationship between age of a farmer and level of profitability $(p<0.01)$ of the dairy cattle enterprises. Younger farmers generate more profits out of the enterprises than their older counterparts. The possible explanation for this is that younger farmers are more likely to efficiently use the taken up improved forage technologies and gain the higher levels of profitability than their older counter parts.

Access to credit had a negative and significant $(p<0.05)$ effect on the level of profitability, which is contrary to what was expected. The plausible explanation could be that farmers accessing credit may be re-allocating money or inputs obtained on credit to other enterprises other than dairy enterprise. This can also explain the negative effect in such a way that those farmers who access credit and allocate it to other enterprises are also likely to take more time on the latter, which may negatively affect the performance of their dairy cattle enterprises.

\section{Conclusions and Recommendations}

Farmers using improved forage technologies (IFT) had lower total production costs per cow per season, and higher average milk production per cow per season compared to the farmers using traditional technology. As such, they had significantly higher revenue and gross margin, five times higher than that of farmers using traditional 
technologies. However, both farmer categories had a positive gross margin. This implies that the dairy cattle enterprises are profitable irrespective of the type of forage technology used.

The interaction effect of profitability and improved cattle was very important in influencing the decision to use IFT. A positive relationship between the number of improved cows and use of IFT indicates that economies of scale were dominant throughout the herd size distribution. However, after accounting for interaction effect between profitability and improved cattle breed, the findings indicated that the inverse relationship dominated the economies of scale up to acquiring one improved cow. The implication is that the type of cattle breed and profitability of the technology were key interdependent factors in influencing the farmers' decision to use IFT. Access to credit and membership to farmer group greatly increased the likelihood of using improved forage technologies, while farmer's age, education level and the size of land owned were very important factors in reducing the probability to use IFT.

Although the dairy cattle enterprises were profitable, whether the farmer used IFT or local feeding technologies, the difference in the returns was significantly higher for IFT users. Policy makers and agencies disseminating forage technologies should aim at provision of extension services that are result-based with demonstrations to encourage farmers to use IFTs. Farmers should be availed with the necessary inputs especially forage seed at a sustainably affordable cost, and shown how to multiply these on their own through training them.

IFTs can also be recommended as possible ways of reducing degradation of agricultural land through over stocking and over-grazing. Supplementing grazing with the planted forages reduces grazing pressure on the land, and allows the farmers to have a higher stocking density without reducing profitability of the enterprise.

Studies that consider long-term impacts should be carried out using larger samples. In addition, there are many improved forage technologies which could perform differently in different areas depending on soils, weather, and climatic conditions among others. Studies should therefore be carried out to evaluate their performance and find out where they perform best.

\section{References}

Adesina, A., \& Zinnah, M. (1993). Technology characteristics, farmers' perceptions and adoption decisions a Tobit model application in Sierra Leone. Agricultural economics, 9, 297-311.

Braumoeller, B.F. (2004). Hypothesis testing and multiplicative interaction terms. International organization, 58, 807-820.

Brambor, T., Clark, W.R. \& Golder, M. (2006). Understanding interaction models: Improving empirical analyses. Political analysis, 14, 63-82.

Foltz, J., \& Lang, G. (2003). The adoption and impact of management intensive rotational grazing (MIRG) on connecticut dairy farms. Renewable agriculture and food Systems, 20 (4), 261-266.

Fufa, B. \& Hassan, R.M. (2006). Determinants of fertilizer use on maize in Eastern Ethiopia: A weighted endogenous sampling analysis of the extent and intensity of adoption. Agrekon, 45 (1), 38-49. http://dx.doi.org/10.1016/S0169-5150(99)00028-6

Gloy, B. A., Tauer, L. W., \& Knoblauch, W. (2002). Profitability of grazing versus mechanical forage harvesting on New York dairy farms. Journal of diary science, 85, 2215-2222.

Greene, W.H. (2003). Econometric Analysis. $5^{\text {th }}$ Ed. Upper Saddle River, New Jersey: Prentice Hall, Pearson Education.

Hanson, G. D., Cunningham, L.C., Morehart, M.J., \& Parsons, R.L. (1998). Profitability of moderate intensive grazing of diary cows in the Northeast. Journal of dairy science, 81 (3), 821-829.

IFAD. (2007). Livestock and range lands; livestock feeding [www page]. URL http://www.ifad.org/llkm/theme/production/feeding.htm

Kabirizi, J. M. L. (2006). Effect of integrating forage legumes in smallholder dairy farming systems on feed availability and animal performance. Unpublished Ph. D thesis, Makerere University, Uganda.

Kauffman, J.B. III, \& Tauer, L.W. (1986). Successful dairy farm management strategies identified by stochastic dominance analyses of farm records. Northeast journal of agricultural and resource economics, 15(2), 168-177.

Lapar, L.M. \& Pandey, S. (1999). Adoption of soil conservation. The case of the Philippine uplands. Agricultural economics, 21 (3), 241-256. http://dx.doi.org/10.1016/S0169-5150(99)00028-6 
McBride, W.D., Short, S., \& El Osta, H. (2004). The adoption and impact of bovine sematotropin on U.S. dairy farms. Review of agricultural economics, 26 (4), 472-488.

Ministry of Finance, Planning and Economic Development (MFPED). (2001). Background to the budget 2001/2002, Kampala, Uganda: Government Printery.

Mugisha, J., Ogwal-O, R., Ekere, W., \& Ekiyar, V. (2004). Adoption of IPM groundnut production technologies in Eastern Uganda. African crop science journal, 12 (4), 383-39.

Obonyo, E. (2000). The adoption of biomass transfer technology in Western Kenya. Unpublished MSc thesis, Kwame Nkrumah University of Science and Technology. Ghana.

Place, F., Franzel, S., DeWolf, J., Rommelse, R., Kwesiga, F., Niang, A., \& Bashir, J. (2000). In: Brendan, B. C. B., Place, F., Aboud, A.A. (2002). Natural resources management in African agriculture: Understanding and improving current practices (p. 155-168). Wallingford: CABI Publishing

Rogers, E.M. (1983). Diffusion of innovations. $4^{\text {th }}$ Ed. New York, U.S.A. Free press.

Salasya, B., Mwangi, W., Mwabu, D. \& Diallo, A. (2007). Factors influencing adoption of stress-tolerant maize hybrid (WH 502) in Western Kenya. African journal of agricultural research, 2 (10), 544-551.

Servier, B.J \& Lee, W.S. (2004). Precision agriculture in Citrus: A probit model analysis for technology adoption. Paper number 041092, publisheb by the American society of agricultural and biological engineers, St. Joseph, Michigan, www.asabe.org

Sserunkuuma, D. (2005). The adoption and impact of improved maize and land management technologies in Uganda. Journal of agricultural and development economics, 2 (1), 67 - 84.

Swinkels, J. M., Hogeveen, H. \& Zadoks, R.N. (2005). A partial budget model to estimate economic benefits of lactational treatment of subclinical Staphylococcus aureus mastitis. Journal of dairy science, 88, 4273-4287.

Teklewold, H. Dadi, L., Yam, A., \& Dana, N. (2006). Determinants of adoption of poultry technology: a double-hurdle approach. Livestock research for rural development, (3) 18.

White, S.L., Benson, G.A., Washburn, S.P. \& Greene, Jr. J.T. (2002). Milk production and economic measures in confinement or pasture systems using seasonally calved Holstein and Jersey cows. Journal of dairy science, 85, 95-104.

Winsten, J. R., Parsons, R. L. \& G. D. Hanson. (2000). A profitability analysis of dairy feeding systems in the Northeast. Agricultural and resource economics review, 29, 220-228.

Wooldridge, J.M. (2002). Econometric analysis of cross section and panel data. Cambridge, MA: MIT Press.

Wünscher T., Schultze-Kraft, R., Peters M. \& Rivas, L. 2004. Early adoption of the tropical forage legume Arachis Pintoi in Huetar Norte, Costa Rica. Experimental agriculture, 40, 257-268.

\section{Notes}

Note 1. Twelve farmers were chosen because of difficulty in accessing farmers using the same forage technologies as those of the NaLIRRI project.

Note 2. From First Order Conditions (FOC), for $Y=\beta_{1} x+\beta_{2} x^{2}$, FOC $\Rightarrow \partial Y / \partial x=\beta_{1}+2 \beta_{2} x=0, \Rightarrow x=-\beta_{1} / 2 \beta_{2}$. 
Table 1. Resource access and utilization by livestock farmers in Soroti district

\begin{tabular}{|c|c|c|c|c|}
\hline Variable & $\begin{array}{r}\text { Entire } \\
\text { Sample } \\
(n=121)\end{array}$ & $\begin{array}{c}\text { Users of } \\
\text { IFT } \\
(n=43) \\
\end{array}$ & $\begin{array}{l}\text { Non-users of IFT } \\
(n=78)\end{array}$ & $\begin{array}{c}\text { t-value/ Chi-Square } \\
\text { value }\end{array}$ \\
\hline Average land owned (hectares) & $16.2(15.8)$ & $18.1(20.5)$ & $15.2(12.6)$ & -0.947 \\
\hline Average land rented (hectares) & $0.7(2.0)$ & $0.5(1.4)$ & $0.8(2.3)$ & 0.705 \\
\hline $\begin{array}{l}\text { Average land borrowed } \\
\text { (hectares) }\end{array}$ & $0.7(2.4)$ & $0.8(3.5)$ & $0.6(1.6)$ & -0.494 \\
\hline $\begin{array}{l}\text { Proportion of land allocated to } \\
\text { cattle rearing }\end{array}$ & $0.23(0.1)$ & $0.24(0.2)$ & $0.23(0.1)$ & -0.216 \\
\hline $\begin{array}{l}\text { \% reporting modes of land } \\
\text { acquisition }\end{array}$ & & & & \\
\hline Inherited & 83.5 & 74.4 & 88.5 & \multirow{3}{*}{3.989} \\
\hline Purchased & 14.9 & 23.3 & 10.3 & \\
\hline Given as a gift & 1.7 & 2.3 & 1.3 & \\
\hline \multicolumn{5}{|l|}{ Cattle ownership } \\
\hline $\begin{array}{l}\text { Average number of local cows } \\
\text { owned }\end{array}$ & $7.4(8.6)$ & $7.2(10.4)$ & $7.6(7.5)$ & 0.257 \\
\hline $\begin{array}{l}\text { Average number of improved } \\
\text { cows owned }\end{array}$ & $0.9(1.4)$ & $1.9(1.4)$ & $0.3(1.0)$ & $-7.421 * * *$ \\
\hline $\begin{array}{l}\text { Experience in livestock } \\
\text { production (years) }\end{array}$ & $9.7(9.9)$ & $10.6(10.9)$ & $9.2(9.3)$ & -0.718 \\
\hline
\end{tabular}

*** implies significant level at 1\%. Figures in parentheses are standard deviations, IFT means improved forage technology.

Table 2. Production costs incurred by users and non-users of IFT

\begin{tabular}{|c|c|c|c|c|}
\hline Variable & $\begin{array}{c}\text { Non-users of IFT } \\
(n=73)\end{array}$ & $\begin{array}{l}\text { Users of IFT } \\
(n=42)\end{array}$ & $\begin{array}{c}\text { Mean } \\
\text { Difference }\end{array}$ & t-value \\
\hline $\begin{array}{l}\text { Labor costs per cow per season } \\
\text { (UgShs) }\end{array}$ & $\begin{array}{r}79898.7 \\
(59313.5) \\
\end{array}$ & $\begin{array}{r}54544.3 \quad(67 \\
570.6) \\
\end{array}$ & 25354.4 & $2.097 * *$ \\
\hline $\begin{array}{l}\text { Other input costs per cow per season } \\
\text { (UgShs) }\end{array}$ & $\begin{array}{r}6520.5 \\
(11477.3) \\
\end{array}$ & $\begin{array}{r}4672.7 \\
(7994.7) \\
\end{array}$ & 1847.8 & 0.922 \\
\hline $\begin{array}{l}\text { Total production costs per cow per } \\
\text { season (UgShs) }\end{array}$ & $\begin{array}{r}86419.2 \\
(64588.8)\end{array}$ & $\begin{array}{r}59217.1 \quad(71 \\
575.4)\end{array}$ & 27202.1 & $2.090 * *$ \\
\hline
\end{tabular}

Figures in parentheses are standard deviation. $* *$ is significance level at $5 \%$. A season was taken as six months.

Table 3. Milk production, consumption and sales by users and non-users of IFT

\begin{tabular}{|l|r|r|r|r|}
\hline Variable & $\begin{array}{c}\text { Non-users of IFT } \\
(\mathbf{n = 6 9 )}\end{array}$ & $\begin{array}{c}\text { Users of IFT } \\
(\mathbf{n = 4 1 )}\end{array}$ & $\begin{array}{c}\text { Mean } \\
\text { Difference }\end{array}$ & t-value \\
\hline Milk production per day (liters) & $6.6(6.0)$ & $10.2(7.7)$ & -3.5 & $-2.692^{* * *}$ \\
\hline Proportion of milk consumed per day & $0.44(0.34)$ & $0.30(0.21)$ & 0.13 & $2.256^{* *}$ \\
\hline Proportion of milk sold per day & $0.56(0.34)$ & $0.69(0.21)$ & -0.13 & $-2.224^{* *}$ \\
\hline $\begin{array}{l}\text { Average and median price of a liter of } \\
\text { milk (UgShs) }\end{array}$ & $\begin{array}{r}381.5(106.4) \\
\{400\}\end{array}$ & $\begin{array}{r}385(128.2) \\
\{400\}\end{array}$ & -0.143 \\
\hline Milk yield (litres per cow per season) & $349.0(220.8)(\mathrm{n}=73)$ & $\begin{array}{r}846.9(613.9) \\
(\mathrm{n}=42)\end{array}$ & -497.9 & $-6.276^{* * *}$ \\
\hline
\end{tabular}

Figures in parentheses are standard deviation and those in braces are medians. *** and $* *$ are significance levels at $1 \%$ and $5 \%$ respectively. 
Table 4. Partial budget results for milk production in Soroti district

\begin{tabular}{|c|c|c|c|c|}
\hline Variables & $\begin{array}{r}\text { Entire sample } \\
(\mathbf{n}=115)\end{array}$ & $\begin{array}{r}\begin{array}{r}\text { Non-users of } \\
\text { IFT } \\
(n=73)\end{array} \\
\end{array}$ & $\begin{array}{r}\text { Users of IFT } \\
(\mathrm{n}=42)\end{array}$ & t-value \\
\hline \multicolumn{5}{|l|}{ 1. Credits (Revenues) } \\
\hline $\begin{array}{l}\text { Average milk production per cow per } \\
\text { season (litres) }\end{array}$ & $\begin{array}{r}530.8 \\
(473.6) \\
\end{array}$ & $\begin{array}{r}349 \\
(220.8) \\
\end{array}$ & $\begin{array}{r}846.9 \\
(846.9) \\
\end{array}$ & $-6.276 * * *$ \\
\hline $\begin{array}{l}\text { Total revenue per cow per season } \\
\text { (UgShs) }\end{array}$ & $\begin{array}{l}212328.4 \\
(189436)\end{array}$ & $\begin{array}{l}\mathbf{1 3 9 5 9 6 . 9} \\
(88303.3)\end{array}$ & $\begin{array}{r}338742.9(245 \\
557.5)\end{array}$ & $-6.276 * * *$ \\
\hline \multicolumn{5}{|l|}{ 2. Debits (variable costs) } \\
\hline Labor costs per cow per season (UgShs) & $\begin{array}{r}70638.9 \\
(63359.1) \\
\end{array}$ & $\begin{array}{r}79898.7 \\
(59313.5) \\
\end{array}$ & $\begin{array}{r}54544.3 \\
(67570.6) \\
\end{array}$ & $2.097 * *$ \\
\hline Other input costs per season (UgShs) & $\begin{array}{r}5845.7 \\
(10343.2) \\
\end{array}$ & $\begin{array}{r}6520.5 \\
(11477.3) \\
\end{array}$ & $\begin{array}{r}4672.7 \\
(7994.7) \\
\end{array}$ & 0.922 \\
\hline Total cost per cow per season (UgShs) & $\begin{array}{r}76484.6 \\
(68193.3)\end{array}$ & $\begin{array}{r}86419.2 \\
(64588.8) \\
\end{array}$ & $\begin{array}{r}\mathbf{5 9 2 1 7 . 1} \\
(71575.4) \\
\end{array}$ & $2.090 * *$ \\
\hline $\begin{array}{l}\text { 3. Gross margin per cow per season } \\
\text { (UgShs) }\end{array}$ & $\begin{array}{r}135843.9(209 \\
917.3) \\
\end{array}$ & $\begin{array}{r}\mathbf{5 3} \mathbf{1 7 7 . 6} \\
(112896.8)\end{array}$ & $\begin{array}{r}279525.7(258 \\
505.1) \\
\end{array}$ & $-6.496 * * *$ \\
\hline Return on inputs $^{\mathrm{a}}$ & $6.3(14.7)$ & $3.1(6.2)$ & $12.3(22.4)^{1}$ & $-3.288 * * *$ \\
\hline
\end{tabular}

${ }^{\mathrm{a}}$ Return on inputs was computed for 39 farmers because three farmers did not incur any costs. Figures in parentheses are standard deviations. $* * *$ and $* *$ are significance levels at $1 \%$ and $5 \%$, respectively.

Table 5. Determinants of use of improved forage technologies

\begin{tabular}{|l|l|l|}
\hline Dependent - use of improved forage technologies =1, 0 otherwise & Coefficients & $\begin{array}{l}\text { Marginal effects } \\
\text { dy/dx) }\end{array}$ \\
\hline Age of farmer & $-0.477^{* * *}(0.154)$ & -0.155 \\
\hline Age of farmer squared & $0.005^{* * *}(0.002)$ & 0.001 \\
\hline Education of farmer (years in school) & $-0.276^{* *}(0.116)$ & -0.090 \\
\hline Number of dependants in a household & $-0.140(0.136)$ & -0.046 \\
\hline Log of land owned (hectares) & $-1.057^{* *}(0.544)$ & -0.343 \\
\hline Log of labor cost in livestock production per season (Ushs) & $-0.167(0.102)$ & -0.054 \\
\hline Number of extension visits per month & $-0.305(0.243)$ & -0.099 \\
\hline Log of distance to the market (km) & $0.393(0.348)$ & 0.127 \\
\hline Membership to any farmers' group =1, 0 otherwise & $3.152^{* * *}(1.073)$ & 0.832 \\
\hline Access to any form of credit =1, 0 otherwise & $1.860^{*}(1.092)$ & 0.381 \\
\hline Experience in livestock production (years) & $-0.063(0.041)$ & -0.021 \\
\hline Number of local cows owned & $-0.291^{* *}(0.138)$ & -0.094 \\
\hline Number of local cows owned squared & $0.014^{* * *}(0.005)$ & 0.005 \\
\hline Number of improved cows owned & $-3.368^{*}(1.828)$ & -1.093 \\
\hline Number of improved cows owned squared & $2.064^{* * *}(0.683)$ & 0.670 \\
\hline Gross Margin (GM) (UgShs) & $0.176(0.344)$ & 0.057 \\
\hline Interaction of GM and number of improved cows owned & $0.823^{* * *}(0.185)$ & 0.267 \\
\hline Interaction of GM and number of improved cows owned squared & $-0.283^{* * *}(0.065)$ & -0.092 \\
\hline Constant & $14.057^{* * *(3.842)}$ & \\
\hline Wald chi2 & $126.92^{* * *}$ & \\
\hline Pseudo R ${ }^{2}$ & 0.816 & \\
\hline Number of observations & 111 & \\
\hline Figs in pan & & \\
\hline
\end{tabular}

Figures in parentheses are standard errors. $* * *, * *$ and $*$ imply significance levels at $1 \%, 5 \%$ and $10 \%$ respectively. 
Table 6. Determinants of profitability of dairy cattle enterprises

\begin{tabular}{|l|l|l|}
\hline \multirow{2}{*}{ Dependent variable=Gross Margin } & \multicolumn{2}{|c|}{ Model } \\
\cline { 2 - 4 } & $\begin{array}{c}\text { Entire } \\
\text { sample }\end{array}$ & $\begin{array}{c}\text { Robust } \\
\text { Std. Err. }\end{array}$ \\
\hline Use of improved forage technology & 292608.7 & $39166.95^{* * *}$ \\
\hline Stocking density (cows per unit grazing area) & 631.51 & $303.56^{* *}$ \\
\hline Stocking density squared & -0.95 & $0.51^{*}$ \\
\hline Experience in livestock production (years) & -322.74 & 1352.78 \\
\hline Age of farmer & 16013.40 & $5547.68^{* * *}$ \\
\hline Age of farmer squared & -164.35 & $63.71^{* *}$ \\
\hline Education of farmer (years in school) & 4608.25 & 3058.73 \\
\hline Number of farmer's dependants & -312.46 & 4698.39 \\
\hline Log of distance to the market $(\mathrm{km})$ & 5917.12 & 9559.13 \\
\hline Membership to any farmers' group $=1,0$ otherwise & -30131.00 & 27140.78 \\
\hline Access to any form of credit $=1,0$ otherwise & -88262.00 & $33898.68^{* *}$ \\
\hline Constant & -358222.00 & $112623.70^{* * *}$ \\
\hline F-value & & $8.47^{* * *}$ \\
\hline R-squared & & 0.54 \\
\hline Number of observations & & 111 \\
\hline
\end{tabular}

$* * *, * *$ and * imply significant levels at $1 \%, 5 \%$ and $10 \%$ respectively. 